\title{
DISTRIBUTION OF HAEMOGLOBIN LEVEL, PACKED CELL VOLUME, AND MEAN CORPUSCULAR HAEMOGLOBIN CONCENTRATION IN WOMEN IN THE COMMUNITY
}

BY

\author{
P. C. ELWOOD*
}

Belfast

The definition of anaemia in most published work appears to depend upon the demonstration of either a haemoglobin level or a mean corpuscular haemoglobin concentration estimation, or both, below levels chosen in a largely arbitrary fashion with little reference to the distributions of these variates in the population.

Pryce (1960) stressed that "normal" haematological values derived from series of selected subjects were likely to be misleading, particularly if the issue was pre-judged by the use of subjects considered to be "idea normals". Likewise a true epidemiological picture of anaemia can be based only on data from a sample which is truly representative of the community from which it is drawn. Selection of subjects from institutions, such as hospitals and clinics, may well imply selection by age and parity, both of which may well be associated with anaemia.

The study reported here was undertaken to determine the distribution of haemoglobin levels, packed cell volumes, and mean cell haemoglobin concentrations in a random sample of healthy women living in Belfast, and to examine the influence of age and parity on these variates.

\section{METHOD}

A sample of 270 names of women was drawn at random from the electoral roll of the city of Belfast. These women were visited in their homes between 6.00 and 9.00 p.m. during May to July, 1962, and specimens of finger-prick blood were taken for examination; if necessary the hand was warmed before the blood was taken. Three specimens $(0.1 \mathrm{ml}$.) were taken for haemoglobin estimation, two were taken in heparinized micro-haematocrit tubes for packed cell volume estimation, and a blood film was made. The age, civil state, and number of

* Now at the M.R.C. Epidemiological Research Unit (South pregnancies (excluding miscarriages) were ascertained for each subject, and each was asked whether or not she was having treatment for any blood condition.

Haemoglobin levels were estimated in g. haemoglobin per $100 \mathrm{ml}$. blood as oxyhaemoglobin in an E.E.L. photo-electric colorimeter (filter Ilford 625) and are stated here as g.Hb. The technique used was checked repeatedly with whole blood standards of known haemoglobin level. Packed cell volumes were measured as percentages after centrifuging for 5 minutes in a Hawksley micro-haematocrit and are stated here as P.C.V. Blood films were stained with Leishman's stain and examined independently by two observers. One observer took all specimens and made all estimations.

The age in years, and the means of the three haemoglobin estimations and of the two packed cell volume estimations for each subject are used in the following analysis, though for a few subjects one packed cell volume estimate had to be discarded because of haemolysis of the specimens. For each subject these means were used to derive the mean corpuscular haemoglobin concentration (M.C.H.C.) which is the ratio of the haemoglobin level (as g.Hb/100 ml. blood) to the packed cell volume (as a percentage), expressed as a percentage.

The sample was examined in groups, defined by parity and civil state as follows:

(i) Single, widowed, and divorced women who had had no pregnancy.

(ii) Married women who had had no pregnancy.

(iii) Women who had had one pregnancy.

(iv) Women who had had two pregnancies.

(v) Women who had had three pregnancies.

(vi) Women who had had four or more pregnancies. 


\section{RESULTS}

Table I gives details of the sample. Four women who had died, and 23 who had moved outside the city after the electoral roll had been compiled but before the time of survey, had been wrongly included in the original sample. These were excluded, as also were women who were in hospital (2), ill at home and under treatment by their doctor (7), pregnant (2), regularly receiving $B_{12}$ following an investigation in hospital for a blood condition (2). No further case of megaloblastic anaemia was detected. There were therefore 230 women within the criteria of the study, and 213 (93 per cent.) of these consented to examination. The analysis and discussion which follows relate to these 213 women.

TABLE I

COMPOSITION OF SAMPLE OF 270 WOMEN WHOSE NAMES WERE DRAWN AT RANDOM FROM THE ELECTORAL REGISTER FOR THE CITY

\begin{tabular}{|c|c|c|c|c|}
\hline \multicolumn{4}{|c|}{ Composition of Sample } & \multirow{2}{*}{$\frac{\begin{array}{c}\text { No. of } \\
\text { Women }\end{array}}{23}$} \\
\hline $\begin{array}{l}\text { Wrongly included in } \\
\text { Sample }\end{array}$ & $\begin{array}{l}\text { Dead } \\
\text { Moved out }\end{array}$ & de the & & \\
\hline Excluded & Ill, pregnar & etc. * & $\ldots$ & 13 \\
\hline $\begin{array}{l}\text { Within the Criteria } \\
\text { of the Study }\end{array}$ & $\begin{array}{l}\text { Examined } \\
\text { Refused } \\
\text { Untraced }\end{array}$ & $\begin{array}{l}\cdots \\
\cdots \\
\cdots\end{array}$ & $\begin{array}{l}\cdots \\
\cdots\end{array}$ & $\begin{array}{r}213 \\
16 \\
1\end{array}$ \\
\hline Total Sample Drawn & $\ldots$ & $\ldots$ & . & 270 \\
\hline
\end{tabular}

* See text.

Table II shows the number and age distributions of the women within each of the six groups defined above. There were significant differences between age distributions $(\mathrm{P}<0.05$ is the criterion of significance throughout).

TABLE II

DISTRIBUTION OF 213 WOMEN BY AGE IN SIX GROUPS (see text)

\begin{tabular}{c|r|r|r|r|r|r}
\hline \multirow{2}{*}{$\begin{array}{c}\text { Age } \\
\text { (yrs) }\end{array}$} & \multicolumn{5}{|c|}{ Group (see text) } \\
& \multicolumn{1}{|c|}{ I } & II & III & IV & V & VI \\
\hline $21-$ & 7 & 1 & 3 & 1 & - & - \\
$25-$ & 15 & 3 & 8 & 11 & 2 & 4 \\
$35-$ & 6 & 4 & 7 & 6 & 3 & 15 \\
$45-$ & 9 & 6 & 5 & 11 & 8 & 9 \\
$55-$ & 2 & 6 & 2 & 5 & 3 & 9 \\
$65-$ & 6 & 1 & 7 & 4 & 1 & 7 \\
$75+$ & 5 & 1 & 1 & - & 2 & 7 \\
\hline All Ages & 50 & 22 & 33 & 38 & 19 & 51 \\
\hline
\end{tabular}

Groups II and III; and Groups IV and V combined.

Ages 21-24 and 25-35; and ages 65-74 and $75+$ combined.

$$
\begin{aligned}
\chi^{2} & =28 \cdot 75 ; \\
\text { D. } & =12 ;
\end{aligned}
$$

$0.01>\mathbf{P}>0.001$
TABLE III

DISTRIBUTIONS OF 213 MEAN ESTIMATIONS OF HAEMOGLOBIN LEVEL (as g.Hb), PACKED CELL VOLUME (as per cent.) AND MEAN CORPUSCULAR HAEMOGLOBIN CONCENTRATION (as per cent.)

\begin{tabular}{|c|c|c|c|c|c|}
\hline \multicolumn{2}{|c|}{$\underset{\text { Level }}{\text { Haemoglobin }}$} & \multicolumn{2}{|c|}{$\begin{array}{l}\text { Packed Cell } \\
\text { Volume }\end{array}$} & \multicolumn{2}{|c|}{$\begin{array}{l}\text { Mean Corpuscular } \\
\text { Haemoglobin } \\
\text { Concentration }\end{array}$} \\
\hline (g.Hb) & No. & (per cent.) & No. & (per cent.) & No. \\
\hline $\begin{array}{c}<10.0 \\
10.0- \\
10.5- \\
11.0- \\
11.5- \\
12.0- \\
12 \cdot 5- \\
13 \cdot 0- \\
13 \cdot 5- \\
14.0- \\
14.5- \\
15.0+\end{array}$ & $\begin{array}{r}6 \\
3 \\
4 \\
7 \\
11 \\
27 \\
37 \\
40 \\
34 \\
27 \\
13 \\
4\end{array}$ & $\begin{array}{l}30- \\
32- \\
34- \\
36- \\
38- \\
40- \\
42- \\
44- \\
46- \\
48+\end{array}$ & $\begin{array}{r}1 \\
8 \\
4 \\
17 \\
37 \\
52 \\
58 \\
20 \\
13 \\
3\end{array}$ & $\begin{array}{l}26- \\
27- \\
28- \\
29- \\
30- \\
31- \\
32- \\
33- \\
34- \\
35- \\
36- \\
37+\end{array}$ & $\begin{array}{r}1 \\
4 \\
5 \\
26 \\
45 \\
61 \\
51 \\
12 \\
6 \\
1 \\
1\end{array}$ \\
\hline Total & 213 & Total & 213 & Total & 213 \\
\hline
\end{tabular}

\section{Distribution OF VARIATES}

Table III shows the distributions of the 213 mean estimations of each variate. All the variates show evidence of significant departures from that expected if they were distributed in accordance with the normal curve, those of haemoglobin levels and P.C.V. show evidence of significant negative skewness, and those of haemoglobin levels and M.C.H.C. show evidence of significant kurtosis. Transformation of each variate to the square of the original units removes the significant skewness in the distribution of P.C.V., and the significant kurtosis in that of both haemoglobin levels and M.C.H.C., but the distribution of haemoglobin levels still shows evidence of significant skewness (Table IV, opposite). The extent of the departure from normal in the distribution of transformed haemoglobin levels was examined by fitting a normal curve to the data and examining the differences between the observed and expected frequencies.

The differences which occur are not significant $\left(\chi^{2}=3 \cdot 25 ;\right.$ D.F. $\left.=3 ; 0.5>P>0 \cdot 3\right)$, and only in the lowest group (in original units, those below 10 g.Hb) is the observed number of estimations greater than that expected (6 observed, 1.89 expected), so it appears likely that it is these low values (in original units, one of $8 \cdot 75$, one of $9 \cdot 25$, and four of $9 \cdot 75$ g.Hb) which give rise to the significant skewness of the transformed variate (Table IV). It is assumed that this departure from normality is not of great importance in the analysis which follows.

Inspection of the data showed that the distribution of each variate in original units does not differ greatly between groups defined by age and parity; in 
TABLE IV

TESTS OF NORMALITY OF THE DISTRIBUTIONS OF 213 MEAN ESTIMATIONS OF HAEMOGLOBIN LEVEL, PACKED CELL VOLUME, AND MEAN COR PUSCULAR HAEMOGLOBIN CONCENTRATION, AS ORIGINAL UNITS AND AS ORIGINAL UNITS

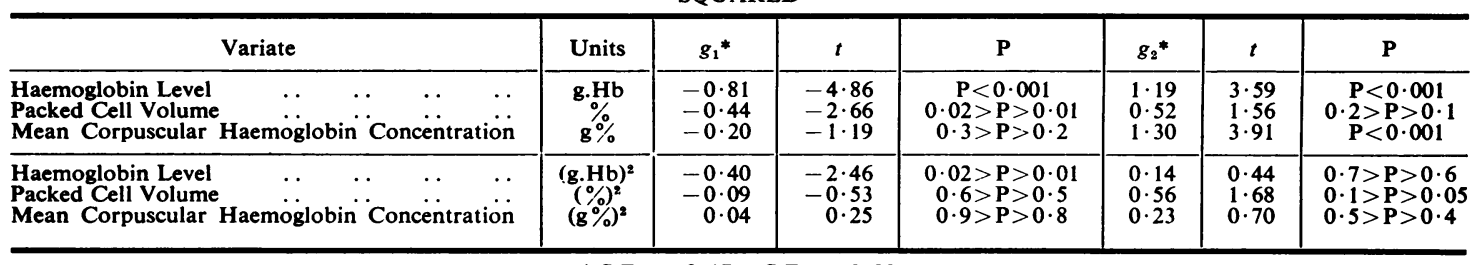

*S.E. $g_{1}=0 \cdot 17 ; \quad$ S.E. $g_{2}=0 \cdot 33$

almost all groups there is evidence of negative skewness in the distribution of haemoglobin levels and P.C.V., and of kurtosis in that of M.C.H.C. Therefore in the subsequent analysis each variate has been transformed to the square of the original units.

\section{Effect of Age ANd Parity}

The linear association between the age in years, and each of the three variates was examined (Table V). Only P.C.V. in certain groups of women shows evidence of a significant linear association with age. The absence of a significant association between haemoglobin level and age was unexpected in view of reports which suggest that the level of this variate may fall after the age of about 60 years (Sunderman, MacFate, MacFayden, Stevenson, and Copeland, 1953). These data were therefore re-examined by curvilinear regression analysis, with (age) ${ }^{2}$ as the second independent variable, and this shows that in several groups of women the association is significant (Table VI).

The correlation coefficients in Tables $\mathrm{V}$ and VI indicate that the proportion of the sums of the squared deviations from regression of each dependent variate which could be "explained" as an effect of age is small in most groups. However, as the association between haemoglobin level and age (Table VI) and between P.C.V. and age (Table V) is
TABLE VI

REGRESSION COEFFICIENTS AND MULTIPLE CORRELATION COEFFICIENTS $(R)$ OF HAEMOGLOBIN LEVEL (as (g.Hb) ${ }^{2}$ ON AGE, AND ON (age) ${ }^{2}$ IN 213 WOMEN IN SIX GROUPS

\begin{tabular}{|c|c|c|c|c|}
\hline \multirow{2}{*}{$\begin{array}{c}\text { Group } \\
\text { (see } \\
\text { text) }\end{array}$} & \multirow{2}{*}{$\begin{array}{c}\text { No. } \\
\text { of } \\
\text { Women }\end{array}$} & \multicolumn{2}{|c|}{ Regression Coefficient } & \multirow{2}{*}{$\boldsymbol{R}$} \\
\hline & & on age & on (age) $)^{2}$ & \\
\hline $\begin{array}{l}\text { I } \\
\text { II } \\
\text { III } \\
\text { IV } \\
\text { V } \\
\text { VI }\end{array}$ & $\begin{array}{l}50 \\
22 \\
33 \\
38 \\
19 \\
51\end{array}$ & $\begin{array}{r}2.07 \pm 1.31 \\
11.08 \pm 2.92 \\
2.12 \pm 2.01 \\
3.44 \pm 2.85 \\
3.93^{*} \pm 1.80 \\
2.15^{*} \pm 0.26\end{array}$ & $\begin{array}{l}-0.02 \pm 0.01 \\
-0.11^{*} \pm 0.03 \\
-0.02 \pm 0.02 \\
-0.04 \pm 0.03 \\
-0.03^{*} \pm 0.02 \\
-0.02^{*} \pm 0.00\end{array}$ & $\begin{array}{l}0.26 \\
0.67 \\
0.36 \\
0.22 \\
0.47 \\
0.20\end{array}$ \\
\hline Overall & 213 & $2 \cdot 23^{*} \pm 0 \cdot 23$ & $-0.02 * \pm 0.01$ & $0 \cdot 22$ \\
\hline
\end{tabular}

* Significant

significant in certain groups, it seems reasonable to suppose that this is a real age effect. It is appropriate therefore to take such effects into account in comparisons of mean haemoglobin levels or P.C.V. between groups, since the latter differ in their age distributions (Table II). In the absence of a significant age effect on M.C.H.C., direct comparisons of means between groups would appear to be valid.

\section{Haemoglobin LeVel}

The variances of the deviations from curvilinear regression of haemoglobin level on age and (age) ${ }^{2}$ are homogenous in the six groups $\left(\chi^{2}=4 \cdot 22 ; \mathrm{D} . \mathrm{F} .=5\right.$;

TABLE V

REGRESSION COEFFICIENTS $(b)$ CORRELATION COEFFICIENTS ( $r$ ) AND DEGREES OF FREEDOM (D.F.) OF HAEMOGLOBIN LEVEL, PACKED CELL VOLUME AND MEAN CORPUSCULAR HAEMOGLOBIN CONCENTRATION ON AGE IN 213

\begin{tabular}{|c|c|c|c|c|c|c|c|}
\hline \multirow{2}{*}{$\begin{array}{c}\text { Group } \\
\text { (see } \\
\text { text) }\end{array}$} & \multirow{2}{*}{$\begin{array}{c}\text { Degrees } \\
\text { of } \\
\text { Freedom }\end{array}$} & \multicolumn{2}{|c|}{$\begin{array}{l}\text { Haemoglobin Level } \\
\text { as (g.Hb) }\end{array}$} & \multicolumn{2}{|c|}{$\begin{array}{l}\text { Packed Cell Volume } \\
\text { as (per cent.) }\end{array}$} & \multicolumn{2}{|c|}{$\begin{array}{l}\text { Mean Corpuscular Haemoglobin } \\
\text { Concentration as (g. per cent.) }\end{array}$} \\
\hline & & $b$ & $r$ & $b$ & $r$ & $b$ & $r$ \\
\hline $\begin{array}{l}\text { II } \\
\text { III } \\
\text { IV } \\
\text { VI } \\
\text { I }\end{array}$ & $\begin{array}{l}49 \\
21 \\
32 \\
37 \\
18 \\
50\end{array}$ & $\begin{array}{r}-0.18 \pm 0.23 \\
0.76 \pm 0.56 \\
0.57 \pm 0.29 \\
0.23 \pm 0.36 \\
-0.01 \pm 0.34 \\
0.29 \pm 0.27\end{array}$ & $\begin{array}{r}-0.11 \\
0.29 \\
0.33 \\
0.11 \\
-0.01 \\
0.15\end{array}$ & $\begin{array}{l}1 \cdot 12 \pm 2 \cdot 14 \\
4 \cdot 68 \pm 5 \cdot 12 \\
5 \cdot 40^{*} \pm 2 \cdot 36 \\
4 \cdot 56 \pm 3 \cdot 13 \\
2.95 \pm 2.95 \\
5 \cdot 53^{*} \pm 2 \cdot 43\end{array}$ & $\begin{array}{l}0 \cdot 08 \\
0 \cdot 20 \\
0 \cdot 38^{*} \\
0 \cdot 23 \\
0 \cdot 24 \\
0 \cdot 31^{*}\end{array}$ & $\begin{array}{r}0.20 \pm 0.62 \\
2.25 \pm 1.10 \\
0.37 \pm 0.84 \\
-0.81 \pm 1.27 \\
-1.85 \pm 1.74 \\
-1.36 \pm 1.05\end{array}$ & $\begin{array}{r}0.05 \\
0.41 \\
0.08 \\
-0.11 \\
-0.25 \\
-0.18\end{array}$ \\
\hline Common & 207 & $0 \cdot 19+0 \cdot 13$ & $0 \cdot 10$ & $3 \cdot 66^{*} \pm 1 \cdot 38$ & $0 \cdot 20^{*}$ & $-0.26 \pm 0.42$ & -0.06 \\
\hline
\end{tabular}

* Significant at $\mathbf{P}<0.05$ 
$0 \cdot 7>\mathrm{P}>0.5$ ) and comparison of the group regression coefficients shows that these do not differ significantly. Therefore comparison of group mean haemoglobin levels adjusted to a common age is valid and this gives no evidence of significant differences between the adjusted group means (Table VII). Inspection of differences between adjusted group means showed that there is some evidence of a fall in mean haemoglobin level with an increase in parity, but this trend is not consistent and the maximum difference between adjusted group means is relatively small (equivalent to about 0.75 g.Hb).

The association between haemoglobin level and age in the present data can therefore best be summarized by the equation:

$$
Y_{1}=2 \cdot 4475 x-0 \cdot 0225 x^{2}+108 \cdot 51,
$$

where $Y_{1}$ is the haemoglobin level in (g.Hb) ${ }^{2}$ and $x$ is the age in years. The standard deviation from regression is $28.7534(\mathrm{~g} . \mathrm{Hb})^{2}$, and the standard errors of the coefficients for age and (age) ${ }^{2}$ are 0.7031 and $0.0068(\mathrm{~g} . \mathrm{Hb})^{2}$ respectively. Both these regression coefficients are highly significant $(\mathrm{P}<$ 0.001 and $0.01>P>0.001$ respectively), but these effects on haemoglobin level are slight compared with other sources of variation.

In fact this regression equation gives estimated levels which are almost identical with those estimated from an equation based on haemoglobin levels in original units:

$$
Y_{2}=0 \cdot 0863 x-0 \cdot 0008 x^{2}+10 \cdot 79,
$$

where $Y_{2}$ is the haemoglobin level in g.Hb and $x$ is the age in years. However, in view of the departure from normality in the distribution of this variate in original units, the use of this latter equation in any problem which involves estimation or comparisons of dispersion may be invalid. While the transformation of the original units which has been used here has failed to remove all evidence of significant skewness, the departures from normal which remained after transformation appear to be slight, and therefore the use of an equation based on squared units would seem to be appropriate in such problems.

\section{Packed Cell Volume}

The variances of the deviations from regression of P.C.V. on age within each group are homogeneous $\left(\chi^{2}=6 \cdot 17 ;\right.$ D.F. $\left.=5 ; 0.3>P>0.2\right)$ and comparison of the group regressions gives no evidence of significant differences between them. Co-variance analysis is therefore appropriate, and after adjustment to a common age, the P.C.V. group means do not differ significantly (Table VIII). Inspection of the differences between adjusted group means reveals that they are very small (up to 0.49 per cent.), and there is no evidence of a consistent change with increasing parity.

The association between P.C.V. and age in these data can therefore be summarized by the regression equation:

$$
Y_{3}=3 \cdot 6634 x+1,484 \cdot 63 \text {, }
$$

TABLE VII

TEST OF SIGNIFICANCE OF OVERALL REGRESSION AND COMPARISON OF GROUP REGRESSIONS OF HAEMOGLOBIN LEVEL ON AGE AND (AGE) ${ }^{2}$, AND COMPARISON OF GROUP MEAN LEVELS ADJUSTED TO A COMMON AGE, IN 213 WOMEN

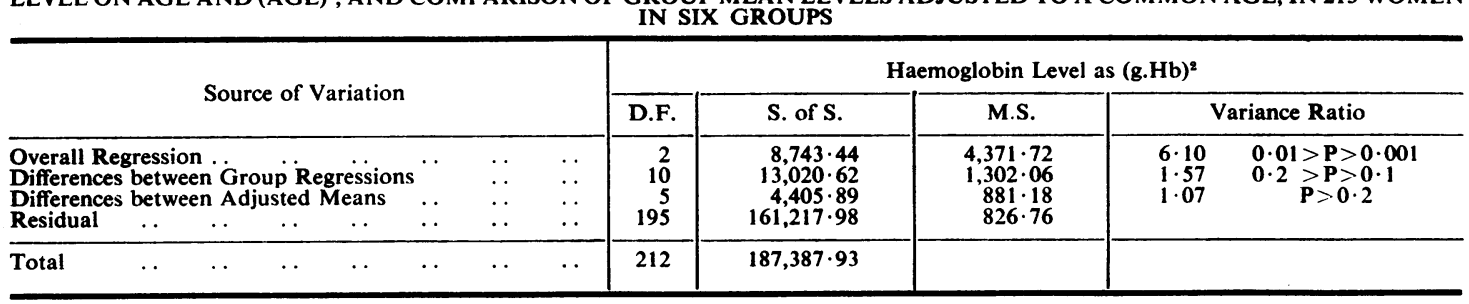

TABLE VIII

TEST OF SIGNIFICANCE OF OVERALL REGRESSION AND COMPARISON OF GROUP REGRESSIONS OF PACKED

\begin{tabular}{|c|c|c|c|c|c|c|c|c|c|c|c|c|}
\hline \multirow{2}{*}{\multicolumn{8}{|c|}{ Source of Variation }} & \multicolumn{5}{|c|}{ Packed Cell Volume (as per cent.) ${ }^{2}$} \\
\hline & & & & & & & & D.F. & S. of $\mathbf{S}$. & M.S. & & riance Ratio \\
\hline \multicolumn{5}{|c|}{$\begin{array}{l}\text { Overall Regression . . . } \\
\text { Differences between Group Regressions } \\
\text { Differences between Adjusted Means }\end{array}$} & $\begin{array}{l}\ddot{*} \\
\ddot{*} \\
\ddot{*}\end{array}$ & $\begin{array}{l}\ddot{*} \\
\cdots \\
\cdots\end{array}$ & $\begin{array}{l}\ddot{*} \\
\ddot{*}\end{array}$ & $\begin{array}{r}1 \\
5 \\
5 \\
201\end{array}$ & $\begin{array}{r}678,601 \cdot 33 \\
197,091 \cdot 07 \\
309,279 \cdot 16 \\
14,834,932 \cdot 74\end{array}$ & $\begin{array}{r}678,601 \cdot 33 \\
39,418 \cdot 21 \\
61,855 \cdot 83 \\
69,810 \cdot 61\end{array}$ & $\begin{array}{l}9 \cdot 72 \\
<1 \\
<1\end{array}$ & $\begin{array}{c}0.01>P>0.001 \\
\mathbf{P}>0.2 \\
\mathbf{P}>0.2\end{array}$ \\
\hline Total & . & $\ldots$ & . & .. & . & .. & $\ldots$ & 212 & $15,214,904 \cdot 30$ & & & \\
\hline
\end{tabular}
CELL VOLUME ON AGE, AND COMPARISON OF GROUP MEANS ADJUSTED TO A COMMON AGE, IN 213 WOMEN IN SIX GROUPS 
where $Y_{3}$ is the P.C.V. as (per cent.) ${ }^{2}$ and $x$ is the age in years. The standard deviation from regression is $264 \cdot 21$ (per cent.) ${ }^{2}$ and the standard error of the regression coefficient, which is highly significant $(0.01>P>0.001)$, is 1.38 (per cent.) ${ }^{2}$, though the age effect in these data is relatively small. The effect of curvilinear regression on these data was examined, adding (age) ${ }^{2}$ as the second independent variable, but in all groups combined the regression coefficient of P.C.V. on (age) ${ }^{2}$ is not significant.

As with haemoglobin level, the use of a regression equation based on P.C.V. in original units gives estimated levels which are almost identical with those obtained by the use of the above equation:

$$
Y_{4}=0 \cdot 0457 x+38 \cdot 44 \text {. }
$$

However, as P.C.V. in original units does not appear to be normally distributed in these data, the same reservations apply to the use of this latter equation as to the equation based on haemoglobin levels in original units.

\section{Mean Corpuscular Haemoglobin Concentration}

Comparison of the variances of these data in the six groups showed that they are homogenous $\left(\chi^{2}=6 \cdot 89 ; D . F .=5 ; 0.3>P>0.2\right)$ and there is no evidence of significant differences between group M.C.H.C. means (Table IX).

TABLE IX

ANALYSIS OF VARIANCE OF 213 ESTIMATIONS OF MEAN CORPUSCULAR HAEMOGLOBIN CONCENTRATION IN 213 WOMEN IN SIX GROUPS

\begin{tabular}{|c|c|c|c|c|}
\hline \multirow{2}{*}{$\begin{array}{l}\text { Source of } \\
\text { Variation }\end{array}$} & \multicolumn{4}{|c|}{$\begin{array}{c}\text { Mean Corpuscular Haemoglobin Concentration } \\
\text { as (per cent.) })^{2}\end{array}$} \\
\hline & D.F. & S. of $\mathbf{S}$. & M.S. & $\begin{array}{l}\text { Variance } \\
\text { Ratio }\end{array}$ \\
\hline $\begin{array}{l}\text { Between Groups } \\
\text { Within Groups }\end{array}$ & $\begin{array}{r}207 \\
5\end{array}$ & $\begin{array}{r}1,947,383 \cdot 39 \\
26,395 \cdot 10\end{array}$ & $\begin{array}{l}9,407 \cdot 68 \\
5,279 \cdot 02\end{array}$ & $178 \quad P>0.2$ \\
\hline Total & 212 & $1,973,778 \cdot 49$ & & \\
\hline
\end{tabular}

In view of the presence of a significant curvilinear association between haemoglobin level and age (Table VI) in the absence of a significant linear association (Table V), the effect was tested of curvilinear regression of M.C.H.C. on age (with (age) ${ }^{2}$ as a second independent variate). No significant effect was detected in all groups combined.

The present data can therefore be summarized without reference to age or parity:

Mean M.C.H.C. in $(\%)^{2}=1,017 \cdot 81$; S.D. $=96.49$; S.E. $=6 \cdot 61$ In original units the mean M.C.H.C. is therefore 31.90 per cent.; the 95 per cent. confidence limits of the population mean are $31 \cdot 70$ and $32 \cdot 11$ per cent.; and 95 per cent. of estimates lie between 28.72 and $34 \cdot 80$ per cent.

\section{Discussion}

The distribution of haemoglobin levels in women in the community has been studied by many workers, though only Kilpatrick and Hardisty (1961) appear to have based their study on a truly random sample of the community. Data presented by the Medical Research Council (1945) and by Berry, Cowin, and Magee (1952) both show negative skewness, and Kilpatrick and Hardisty (1961) in a random sample of 180 women aged 55-64 years in a South Wales mining valley found significant negative skewness in the distribution of their haemoglobin levels. The present data support these findings and in addition suggest that the distribution of M.C.H.C. in women in the community may be non-normal although there is no evidence of asymmetry in its distribution. The use of a mean level of haemoglobin in a group of women may therefore be misleading, and tests of significance of differences between group means and estimates of confidence limits, in the absence of suitable transformation, may be invalid for either haemoglobin or M.C.H.C. levels.

The absence of obvious skewness in the distribution of haemoglobin levels in male subjects, in whom anaemia is relatively uncommon (Medical Research Council, 1945; Kilpatrick and Hardisty, 1961) would suggest that, in the absence of anaemia, the distribution of haemoglobin levels in women may be normal. The negative skewness in the observed distribution is most probably caused by a distribution of levels in anaemic women being superimposed on that in non-anaemic women, the former distribution being shifted towards the lower levels, but not to an extent sufficient to become discrete. As it is most unlikely that either of the two distributions is truncated, the definition of any single level of haemoglobin in an attempt to discriminate between them will only separate two groups in each of which anaemic and non-anaemic women will be represented in varying proportions. "Anaemia" defined thus can only imply the presence of a haemoglobin level below a defined level and cannot be synonymous with any disease or deficiency.

These limitations would seem to apply equally to the use of a single level of M.C.H.C. in an attempt to define anaemia as there is no evidence in the distribution of this variate of two discrete populations.

The effect of age on haemoglobin level in women is controversial. Some authors have reported a gradual fall in mean level in women with increasing age up to 50 years followed by a small mean rise (Davidson and Fullerton, 1938; Medical Research Council, 1945). However, Sunderman and others (1953), in a review of the literature, concluded that there is probably little variation in haemoglobin 
level during adult life, though "the majority (of authors) agrees that a slight diminution in haemoglobin values become progressively apparent after the age of 60 ". The present data suggest that there is a slight rise during adult life to a maximum at age 54 years followed by a fall. The effect of age appears to be weak, though highly significant in the present data. However, this is not entirely unexpected, as age is only one of many factors which may influence haemoglobin level.

The presence of a significant association between age and haemoglobin level would indicate that the designation of a single level of haemoglobin as a criterion of anaemia in women cannot be justified, and the estimation of the prevalence of anaemia, so defined, in groups of women, or the comparison of its prevalence in different groups, without reference to the age distribution within the groups, may be misleading. World Health Organization (1959) suggest that anaemia may be diagnosed on the demonstration of a haemoglobin level below 12.0 g.Hb, and it is therefore of interest that, using this criterion of anaemia, its prevalence on the basis of the present data, at ages $25,35,45,55,65$, and 75 years, is about $18,15,12,11$, and 15 per cent. respectively. While this trend could be a reflection of the true prevalence of anaemia in the community, it seems much more likely that it is, in part at least, an effect of a real association of haemoglobin level with age.

Kilpatrick and Hardisty (1961) showed that, in a random sample of males in South Wales, M.C.H.C. fell significantly with increasing age, though the extent of the mean fall was only about 0.03 per cent. per year. However, data published by Snell (1950) show virtually no change in M.C.H.C. during adult life in Japanese female subjects. The present data also fail to show a significant association between these factors and so the omission of a reference to age in any criterion of anaemia in women based on the M.C.H.C. level appears to be reasonable. The lower limit of the "normal range" of M.C.H.C. in female subjects is usually stated to be 32.0 per cent. (Wintrobe, 1934 and 1961; Britton, 1963), and it is of interest therefore that the proportion of women of all ages in this study with a haemoglobin level which may, on the criterion suggested by World Health Organization (1959), be considered to be anaemic is 15 per cent., and the M.C.H.C. level below which 15 per cent. of the present data fall is 30.70 per cent.

The Medical Research Council (1945) showed that parous women had, on average, a lower haemoglobin level than nulliparous women although the differences were very small. Berry and others (1952) failed to confirm this finding but observed that women who had had four or more pregnancies had a lower mean level than those who had had three or fewer pregnancies. All these workers, however, omitted a correction for possible age differences between women of different parities, and Sunderman and others (1952), in a review of the literature, found the evidence for an association between parity and haemoglobin level to be conflicting. While the present data are in accord with a mean fall in haemoglobin level with increasing parity, independent of age, the change is very small and is not significant, and there is no evidence of any association between M.C.H.C. and parity.

\section{SUMMARY}

A study of haemoglobin level, packed cell volume (P.C.V.), and mean corpuscular haemoglobin concentration (M.C.H.C.) in 93 per cent. (213) of a random sample of healthy women in Belfast is reported. All these variates showed evidence of significant (at $\mathrm{P}<0.05$ ) departures from those expected were they distributed in accordance with the normal curve, that of haemoglobin level showed significant negative skewness and kurtosis, that of P.C.V. significant negative skewness, and that of M.C.H.C. significant kurtosis.

After transformation of the original units of each variate, a significant curvilinear association between age and haemoglobin level and a significant linear association between age and P.C.V. were found, but there was no evidence of a significant association between age and M.C.H.C. There was no significant association between any of the variates and parity, independent of age.

It is suggested that the use of a mean haemoglobin level, or tests of the significance of differences between mean haemoglobin or M.C.H.C. levels in groups of women, may be misleading. Furthermore, discrimination between "anaemic" and "non-anaemic" women by the definition of a single haemoglobin or M.C.H.C. level would appear to be impossible, and any criterion of anaemia based on haemoglobin level without reference to age appears to be incapable of justification.

I wish to thank Prof. J. Pemberton for encouragement and help, Prof. E. A. Cheeseman for statistical advice, Miss T. Pitt for computing assistance, Mr R. McClaren for considerable assistance with laboratory work and microscopy, Mrs D. Kyle, the Misses E. Kyle, J. Broderick, D. Agnew, and my wife, who gave invaluable help in the field work, and Drs C. Cotton Kennedy and J. S. Elwood who gave helpful criticism of this report. 


\section{REFERENCES}

Berry, W. T. C., Cowin, P. J., and Magee, H. E. (1952). Brit. med. J., 1, 410.

Britton, C. J. C. (1963). "Whitby and Britton Disorders of the Blood", 9th ed. Churchill, London.

Davidson, L. S. P. and Fullerton, H. W. (1938). Edinb. med. J., 45, 1 .

Kilpatrick, G. S., and Hardisty, R. M. (1961). Brit. med. J., $1,778$.

Medical Research Council (1945). Spec. Rep. Ser. med. Res. Coun., Lond., No. 252.
Pryce, J. D. (1960). Lancet, 2, 333.

Snell, F. M. (1950). Blood, 5, 89.

Sunderman, F. W., MacFate, R. P., MacFayden, D. A. Stevenson, G. F., and Copeland, B. E. (1953). Amer. J. clin. Path., 23, 519.

Wintrobe, M. M. (1934). Arch. intern. Med., 54, 256. (1961). "Clinical Hematology", 5th ed. Kimpton, London.

World Health Organization. (1959). Wld Hlth Org. Techn. Rep. Ser., No. 182. 